\title{
Denitrification from nitrogen-fixing biologically crusted soils in a cool desert environment, southeast Utah, USA
}

\author{
Nichole N Barger ${ }^{1 *}$, Sarah C Castle ${ }^{2}$ and Gavin N Dean ${ }^{1}$
}

\begin{abstract}
Introduction: Nitrogen fixation by microorganisms within biological soil crust ("biocrust") communities provides an important pathway for $\mathrm{N}$ inputs in cool desert environments where soil nutrients are low and symbiotic $\mathrm{N}$-fixing plants may be rare. Estimates of $\mathrm{N}$ fixation in biocrusts often greatly exceed that of $\mathrm{N}$ accretion rates leading to uncertainty regarding $\mathrm{N}$ loss pathways.

Methods: In this study we examined nitrogen fixation and denitrification rates in biocrust communities that differed in $\mathrm{N}$ fixation potential (low $\mathrm{N}$ fixation = light cyanobacterial biocrust, high $\mathrm{N}$ fixation $=$ dark cyanolichen crust) at four temperature levels $\left(10,20,30,40^{\circ} \mathrm{C}\right)$ and four simulated rainfall levels $(0.05,0.2,0.6,1 \mathrm{~cm}$ rain events) under controlled laboratory conditions.

Results: Acetylene reduction rates (AR, an index of $\mathrm{N}$ fixation activity) were over six-fold higher in dark crusts relative to light crusts. Dark biocrusts also exhibited eight-fold higher denitrification rates. There was no consistent effect of temperature on denitrification rates, but there was an interactive effect of water addition and crust type. In light crusts, denitrification rates increased with increasing water addition, whereas the highest denitrification rates in dark crusts were observed at the lowest level of water addition.

Conclusions: These results suggest that there are no clear and consistent environmental controls on short-term denitrification rates in these biologically crusted soils. Taken together, estimates of denitrification from light and dark biocrusts constituted 3 and $4 \%$ of $\mathrm{N}$ fixation rates, respectively suggesting that losses as denitrification are not significant relative to $\mathrm{N}$ inputs via fixation. This estimate is based on a previously published conversion ratio of ethylene produced to $\mathrm{N}$ fixed that is low (0.295), resulting in high estimates of $\mathrm{N}$ fixation. If future $\mathrm{N}$ fixation studies in biologically crusted soils show that these ratios are closer to the theoretical 3:1 ratio, denitrification may constitute a more significant loss pathway relative to $\mathrm{N}$ fixed.
\end{abstract}

Keywords: Biological soil crust, Colorado Plateau, Cool desert, Denitrification, Nitrogen fixation, Soil nitrogen cycling

\section{Introduction}

Biological soil crusts ("biocrusts") are diverse communities of cyanobacteria, algae, lichens, mosses, fungi, and other bacteria, which exist in open soil areas not favorable for the growth of higher autotrophs. They comprise up to $70 \%$ of the living cover at many sites in arid and semi-arid regions of the western United States (Belnap et al. 2001), contributing to a broad range of ecological

\footnotetext{
* Correspondence: nichole.barger@colorado.edu

'Department of Ecology and Evolutionary Biology, University of Colorado,

Campus Box 334, Boulder, CO 80309-0334, USA

Full list of author information is available at the end of the article
}

functions. One such function of primary importance in dryland ecosystems is the ability of microorganisms within biocrusts to fix atmospheric nitrogen (N) (Mayland and McIntosh 1966; Zaady et al. 1998; Evans and Belnap 1999; Hartley and Schlesinger 2002; Billings et al. 2003; Johnson et al. 2007). Nitrogen fixation by microorganisms within biocrust communities provides an important pathway for $\mathrm{N}$ inputs in cool desert environments that are characteristically low in nutrient availability and have a paucity of symbiotic $\mathrm{N}$-fixing plants.

What has been less clear is the fate of the $\mathrm{N}$ fixed by biocrust organisms and whether $\mathrm{N}$ fixed is retained 
within the ecosystem. Estimates of $\mathrm{N}$ fixation in biocrusts often greatly exceed that of $\mathrm{N}$ accretion rates (Peterjohn and Schlesinger 1990), leading to uncertainty regarding the fate of the fixed $\mathrm{N}$ by biologically crusted soils and the potentially important $\mathrm{N}$ loss pathways. Soils in dryland ecosystems are characterized by pulse precipitation events resulting in wet and drying cycles. These pulsed dynamics in soils may result in N "leakage" by biological soil crust organisms to the surrounding soil environment in such forms as $\mathrm{NH}_{4}{ }^{+}$and other soluble organic nitrogen compounds (Mayland and McIntosh 1966; Johnson et al. 2007). Nitrogen leakage from biocrusts may not only enhance soil nutrient availability to support plant growth (Mayland and McIntosh 1966; Belnap and Harper 1995 but may also be lost from the system via gaseous $\mathrm{N}$ loss in transformations related to nitrification and denitrification processes (Zaady 2005; Barger et al. 2005; Johnson et al. 2007; Strauss et al. 2012; Brankatschk et al. 2013).

Denitrification is the biological process that occurs under reducing conditions where $\mathrm{NO}_{3}^{-}$is used by denitrifying bacteria (primarily heterotrophic bacteria) in the absence of $\mathrm{O}_{2}$ as an electron acceptor. $\mathrm{NO}_{3}{ }^{-}$is converted to $\mathrm{NO}, \mathrm{N}_{2} \mathrm{O}$ and $\mathrm{N}_{2}$ along a reduction pathway. Factors regulating denitrification rates are low $\mathrm{O}_{2}$ partial pressure, available $\mathrm{NO}_{3}{ }^{-}$to serve as an oxidant, and organic $\mathrm{C}$ as an energy source for heterotrophic bacteria (Williams et al. 1992). Previously, it was thought that denitrification in dryland ecosystems should be low because anaerobic conditions should rarely occur in arid environments. However, the presence of anaerobic microsites within dryland soils is not as rare as previously believed with oxygen levels reaching near zero in the surface soils (Garcia-Pichel and Belnap 1996; Johnson et al. 2007). A large portion of the microbial community resides in the top few millimeters of dryland soils. Thus a pulse in microbial activity after a rain event may quickly reduce soil oxygen levels (Garcia-Pichel and Belnap 1996; Johnson et al. 2007).

Estimates of denitrification are highly variable in desert ecosystems ranging from 0.4 to $9 \mathrm{~kg} \mathrm{~N} \mathrm{ha}^{-1}$ year $^{-1}$ in hot North American deserts (e.g., Chihuahuan and Sonoran) (Virginia et al. 1982; Peterjohn and Schlesinger 1991; Guilbault and Matthias 1998; Schade et al. 2002). In soils from a cold desert site on the Colorado Plateau, denitrification was estimated as high as $19 \mathrm{~kg} \mathrm{~N} \mathrm{ha}^{-1}$ year $^{-1}$ (West and Skujins 1977). These highly variable estimates are likely driven by high spatial and temporal variability (e.g., hot spots and hot moments) in denitrification rates. Both biotic and abiotic processes drive patterns in resource distribution in dryland ecosystems resulting in accumulation of nutrients beneath shrub and tree canopies relative to interspace soils in what has been previously described as "islands of fertility" (Noy-Meir 1985; Schlesinger and
Pilmanis 1998). At a Sonoran desert site, Virginia et al. (1982) reported a 58-fold increase in denitrification rates under Prosopis glandulosa, an $\mathrm{N}$-fixing shrub, as compared to plant interspaces. These patterns in denitrification suggest that high $\mathrm{N}$ availability associated with $\mathrm{N}$ fixation is an important driver of this process.

Past studies of denitrification in biologically crusted soils have yielded a wide range of denitrification rates. Denitrification rates within surface soils (i.e., top $1 \mathrm{~cm}$ ) containing biocrusts were negligible relative to other $\mathrm{N}$ loss pathways (Johnson et al. 2007; Strauss et al. 2012) or increased with biocrust development (Brankatschk et al. 2013). These studies, however, evaluated denitrification from biologically crusted soils at a single temperature and soil moisture level, environmental conditions that may strongly influence not only $\mathrm{N}$ fixation but also denitrification rates.

Following this, our objective was to examine the influence of biocrust community on denitrification rates across a range of environmental conditions in the lab to better understand the potential for denitrification from biocrust communities in dryland ecosystems. We hypothesized that denitrification rates would increase with increasing $\mathrm{N}$ fixation potential of the biocrust community and that environmental conditions such as temperature and soil moisture would further influence these rates. In this study, we examined nitrogen fixation and denitrification rates in two biocrust communities that differed in their $\mathrm{N}$ fixation potential (light cyanobacterial biocrust and dark cyanolichen crust) at four temperature levels $\left(10,20,30,40^{\circ} \mathrm{C}\right)$ and four simulated rainfall levels $(0.05,0.2,0.6,1 \mathrm{~cm}$ rain events) under controlled laboratory conditions.

\section{Methods}

\section{Site description}

In the spring of 2009, intact biocrust cores were collected to a $5 \mathrm{~cm}$ depth near the Island-in-the-Sky District of Canyonlands National Park, UT $\left(38^{\circ} 33^{\prime} 19.7^{\prime \prime} \mathrm{N}\right.$, $109^{\circ} 44^{\prime} 38.8^{\prime \prime} 1,883$ m.a.s.l.). Mean annual precipitation in this area was $231 \mathrm{~mm}$ ranging from a low of $179 \mathrm{~mm}$ to a high of $327 \mathrm{~mm}$ in the 10 years prior to our study (NADP site UT09). Throughout Canyonlands, welldeveloped biocrust communities often occur on Rizno, dry-Rock outcrop soils, which are classified as loamy, mixed calcareous, mesic Lithic Ustic Torriorthents (Web Soil Survey, http://websoilsurvey.nrcs.usda.gov/app/Home Page.htm). High sand content and low organic C and N characterize these soils.

\section{Sample collection}

Visual inspection of the presence of lichen species and coloration in biocrusts is a strong indicator of biocrust community structure and function across the cool desert 
regions of the western U.S. (Barger et al. 2005; Belnap et al. 2008). In our study we used visual inspection of biocrust color in the field to evaluate the $\mathrm{N}$ fixation potential of the biocrust community. "Light" biologically crusted soils are often dominated by the free-living filamentous cyanobacteria Microcoleus vaginatus and $M$. steenstruppi (Gundlapally and Garcia-Pichel 2006) with little to no presence of dark pigmented cyanobacteria (Yeager et al. 2004). In contrast, "dark" biologically crusted soils contain not only Microcoleus spp. but also the darker pigmented cyanobacteria such as Scytonema myochrous and Nostoc commune (Yeager et al. 2004; Gundlapally and Garcia-Pichel 2006). In addition to these cyanobacterial organisms, the $\mathrm{N}$-fixing lichens Collema tenax and C. coccophorum may also be present on dark biologically crusted soils. Coloration is not only an indicator of microorganism composition but also biocrust function. Chlorophyll a (chla), exopolysaccharide, and soil aggregate stability are strongly and positively correlated with biocrust darkness (Belnap et al. 2008).

In the field, biocrusts were gently covered with a towel and wet by a watering can with distilled water in order to minimize breaking of the crust surface during sampling. We used a $5.3 \mathrm{~cm}$ diameter polyvinyl chloride (PVC) cylinder to core the soil and then gently retrieved the core with a spatula and fitted the bottom with a plastic cap. Sampling was done within the soil type described above within a $30 \times 30 \mathrm{~m}$ area. We collected 64 cores from both light and dark biocrusts for a total of 128 cores. Following collection, soils within the PVC cylinders were allowed to dry immediately in overcast/ sunny conditions and transported to the laboratory.

Although we based our field collections on visual assessment of coloration, we further quantified biocrust cover in the lab. Biocrust cover was measured for each $22 \mathrm{~cm}^{2}$ core using the point-intercept method. A small wire grid with evenly spaced cells was placed on the surface of each core. Cover at each point on the grid was classified using the six different cover classes: light cyanobacteria, dark cyanobacteria, Collema lichens, all other lichens, moss, and rock.

To examine the influence of water addition and temperature on nitrogen fixation and denitrification rates, we conducted a full factorial design of biocrust color (dark, light), simulated rain event size $(0.05,0.2$, $0.6,1 \mathrm{~cm})$, and temperature $\left(10,20,30,40^{\circ} \mathrm{C}\right)$ in the laboratory. Within the light and dark biocrusts, each core received water addition to simulate rain events of a specific size. The four rain event sizes were chosen to represent the amount of water these biocrust organisms may experience under field conditions. Each of these cores was then incubated at one of the four experimental temperatures. There were four replicates within each level of rain event and incubation temperature.

\section{Acetylene reduction assay}

Incubation chambers were constructed of mason jars that were pre-drilled through the glass bottom and plugged with a stopper that had a small section of glass tubing fitted with half-hole septa. When incubation chambers were assembled, crust cores were placed on the jar lid and the jar was turned upside down, allowing cores to be fully exposed to the incubation lights. Biocrusts were wetted with deionized water at the levels described above and placed in incubators in open mason jars for a period of $4 \mathrm{~h}$ at the desired temperature. Following the pre-incubation period, jars were plugged with rubber stoppers to form an airtight chamber and a $10 \%$ acetylene atmosphere was created in each chamber by first removing a volume of headspace and replacing that same volume with acetylene gas. Acetylene gas was made in the lab by reacting calcium carbide with water and trapping the gas generated from the reaction in an airtight gas sampling bag. After the $4 \mathrm{~h}$ pre-incubation, biocrust cores were immediately incubated in the presence of the acetylene atmosphere for an additional $2 \mathrm{~h}$. Following the $2 \mathrm{~h}$ incubation, a gas sample was drawn from the chambers using an airtight syringe fitted with a needle and injected into pre-evacuated Exetainers (Labco Limited, UK). Ethylene and $\mathrm{N}_{2} \mathrm{O}$ gas were simultaneously analyzed by gas chromatography (Shimadzu, Columbia, MD) equipped with both an FID and an ECD, such that there was a front flush mechanism in order to prevent acetylene exposure to the ECD, and fitted with a $1 \mathrm{~cm}$ sample loop.

\section{Soil processing}

Following incubation, biocrust cores were cut into crosssections of the $0-2$ and $2-5 \mathrm{~cm}$ sections. Total soil mass of each sub-sample was recorded. Each horizon was homogenized and then split for different analyses. A subsample of each horizon was extracted immediately with $40 \mathrm{~mL}$ of $2 \mathrm{M} \mathrm{KCl}$ for $1 \mathrm{~h}$ on a reciprocal shaker. Soil extracts were filtered (Whatman \#1) and were immediately frozen. $\mathrm{NH}_{4}^{+}$concentrations were analyzed using the phenol-hypochlorite reaction described by Weatherburn (1967), and $\mathrm{NO}_{3}{ }^{-}$was determined using a method adapted from Doane and Horwáth (2003). Both $\mathrm{NH}_{4}{ }^{+}$ and $\mathrm{NO}_{3}{ }^{-}$were determined colorimetrically using a microplate reader (Biotek, Winooski, VT). An additional subsample of each horizon was dried at $105^{\circ} \mathrm{C}$ for gravimetric water content determination. Samples from each horizon were split and oven dried $\left(60^{\circ} \mathrm{C}\right)$ for organic carbon $[\mathrm{C}]$ and $\mathrm{N}$ analysis. Total organic soil $\mathrm{C}$ and $\mathrm{N}$ measurements were made on a CHN 4010 Elemental Combustion System (Costech Analytical Technologies, Valencia, CA). All C and $\mathrm{N}$ analyses were calibrated with an atropine standard. Soil inorganic carbon was determined using the modified pressure transducer method 
(Sherrod et al. 2002). A subsample of the $0-2 \mathrm{~cm}$ sample was removed for chla analysis and air-dried, sieved, and ground. Chla was extracted with ethanol (Castle et al. 2011) and assessed spectrophotometrically (Beckman DU-64, Beckman Instruments Inc., Fullerton, CA). Soil texture was determined using a modified rapid method procedure described by Kettler et al. (2001), which involved removing carbonates and organic matter using sodium acetate and sodium hypochlorite, respectively.

\section{Statistical analyses}

Acetylene reduction (AR) assay data and denitrification rates were log transformed to meet the assumptions of parametric statistical tests. Denitrification rates were highly variable across samples. Thus denitrification rates that were greater than three standard deviations from the mean were removed before analysis. When this cutoff was applied, only one dark biocrust core incubated at $30^{\circ} \mathrm{C}$ with a $0.5 \mathrm{~cm}$ water addition was removed from the analysis. We conducted a three-way analysis of variance (ANOVA) of AR activity, denitrification rates, and inorganic $\mathrm{N}$ pools evaluating the two crust types (light, dark), four levels of temperature, and four levels of moisture (IBM SPSS Statistics 20.0).

\section{Results and discussion}

\section{Soil characterization}

The "light" and "dark" visual characterization of biocrust types when collecting the soil samples in the field delineated clear differences in cyanobacterial composition and N-fixing lichen cover. The light biocrust cores were composed of $95 \%$ light cyanobacterial crust cover and only $3 \%$ dark crust cover. In contrast the percent dark crust cover in the dark crust cores was $87 \%$ with only $5 \%$ cover characterized as light crust (Table 1). In addition to darker pigmented cyanobacteria, the $\mathrm{N}$-fixing Collema lichens comprised approximately $6 \%$ cover in the dark crust cores. Chla content, which is an index of cyanobacterial biomass and $\mathrm{N}$ fixation potential of the biocrusts, was nearly two-fold higher in the dark crusts relative to the light crusts (Table 1). Moss cover across both light and dark was low and ranged from 2 to $3 \%$ (Table 1).

\section{Nitrogen fixation}

Acetylene reduction rates were over six-fold higher in dark biocrusts relative to light biocrusts [mean $( \pm 1 \mathrm{SE})$ $\mu \mathrm{mol} \mathrm{m} \mathrm{m}^{2} \mathrm{~h}^{-1}$ light $=0.13(0.05)$, dark $\left.=0.86(0.26)\right]$. There was an interactive effect of biocrust type and water additions, in that water additions increased AR rates only in dark biocrusts but had no effect on light biocrusts (Figure 1A, B; crust $\times$ water; $F=4.6, P=0.005$ ). Temperature also influenced AR rates, but again, temperature effects were only observed in dark biocrusts (crust $\times$ temperature; $\mathrm{F}=4.6, P=0.005$ ). Within dark
Table 1 Biocrust biological, physical, and chemical characteristics

\begin{tabular}{lllll}
\hline Soil measurement & Unit & Number & Light & Dark \\
\hline Chlorophyll a & $\mu$ g g soil ${ }^{-1}$ & 64 & $3.8(0.24)$ & $6.5(0.28)$ \\
Crust cover & & & & \\
Light crust & \% cover & 64 & $94.8(1.0)$ & $4.5(1.7)$ \\
Dark crust & \% cover & 64 & $3.3(0.9)$ & $87.0(2.6)$ \\
Collema & \% cover & 64 & $0.1(0.1)$ & $6.0(1.6)$ \\
Other lichen & \% cover & 64 & $0.0(0.0)$ & $1.1(0.4)$ \\
Rock & \% cover & 64 & $0.1(0.1)$ & $0.1(0.1)$ \\
Moss & \% cover & 64 & $1.8(0.4)$ & $2.5(0.6)$ \\
Soil texture (0-5 cm) & & & & \\
Sand & \% by mass & 16 & $82.3(0.6)$ & $82.6(0.6)$ \\
Silt & \% by mass & 16 & $13.3(0.8)$ & $13.5(0.7)$ \\
Clay & \% by mass & 16 & $4.4(0.4)$ & $3.9(0.4)$ \\
Chemical & & & & \\
characteristics & & & & \\
Soil organic C 0-2 cm & \% by mass & 64 & $0.32(0.02)$ & $0.41(0.01)$ \\
Soil organic C 2-5 cm & \% by mass & 64 & $0.31(0.01)$ & $0.27(0.01)$ \\
Soil total N 0-2 cm & \% by mass & 64 & $0.032(0.001)$ & $0.041(0.001)$ \\
Soil total N 2-5 cm & \% by mass & 64 & $0.028(0.001)$ & $0.026(0.001)$ \\
\hline Values are mean \pm 1 SE & & & &
\end{tabular}

Values are mean $\pm 1 \mathrm{SE}$.

crusts, optimal temperatures for $\mathrm{N}$ fixation were in the range of $10-30^{\circ} \mathrm{C}$ with a peak at $20^{\circ} \mathrm{C}$ and declined to near zero at $40^{\circ} \mathrm{C}$ (Figure $\left.1 \mathrm{~B}\right)$.

The higher $\mathrm{N}$ fixation rates in dark crust were likely due not only to the presence of the $\mathrm{N}$-fixing Collema spp. but also the higher level of $\mathrm{N}$-fixing cyanobacteria as supported by the nearly two-fold greater soil chl $a$ in dark biocrust soils relative to light biocrusts (Table 1). Overall, these results are consistent with patterns and controls on $\mathrm{N}$ fixation in biologically crusted soils in cool desert environments, confirming that dark biologically crusted soil has higher $\mathrm{N}$ fixation potential than light crusts with optimal temperatures for fixation occurring around $20^{\circ} \mathrm{C}$ (Belnap 2002; Johnson et al. 2007).

\section{Denitrification}

Denitrification rates were on average eight-fold higher in dark biocrusts as compared to light biocrusts [mean denitrification $\left(\mu \mathrm{g} \mathrm{N}_{2} \mathrm{O}-\mathrm{N} \mathrm{m}^{2}\right.$ day $\left.^{-1}\right)$ : light $=48$, dark $=418$; Figure 2), which supports our hypothesis that denitrification increases with increasing $\mathrm{N}$ fixation potential of the biocrust community. Overall denitrification rates were in the mid range of previously reported estimates for similar light and dark biocrust communities in this region (Johnson et al. 2007; Strauss et al. 2012) but dramatically lower than values reported for early and later successional biocrusts located on a central European inland dune 


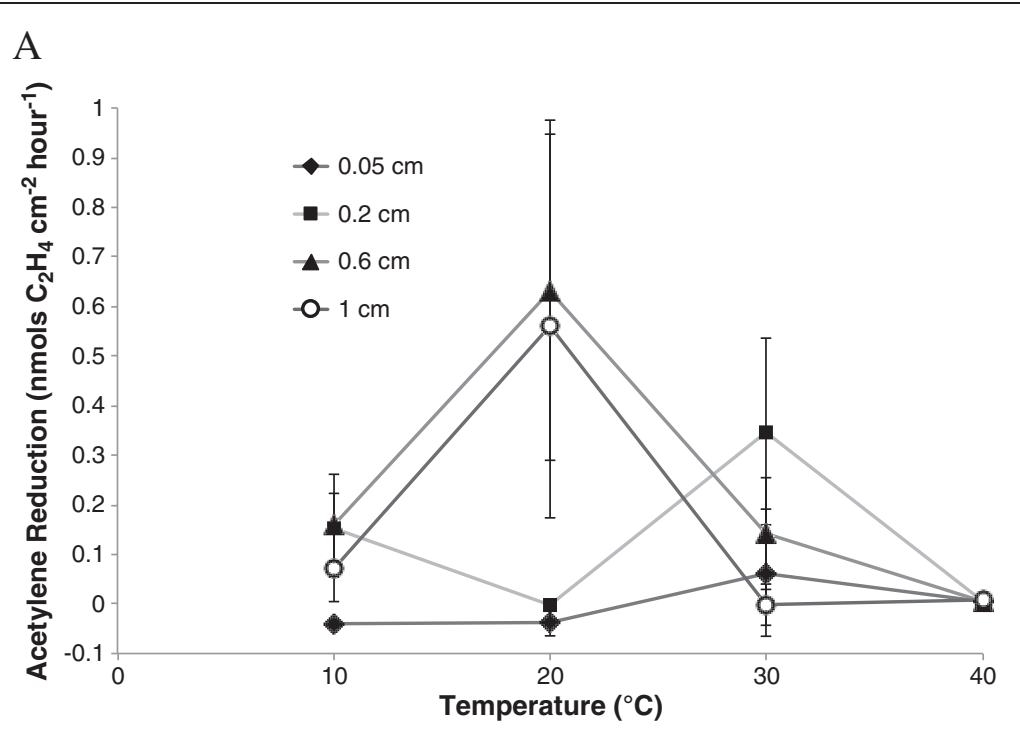

B

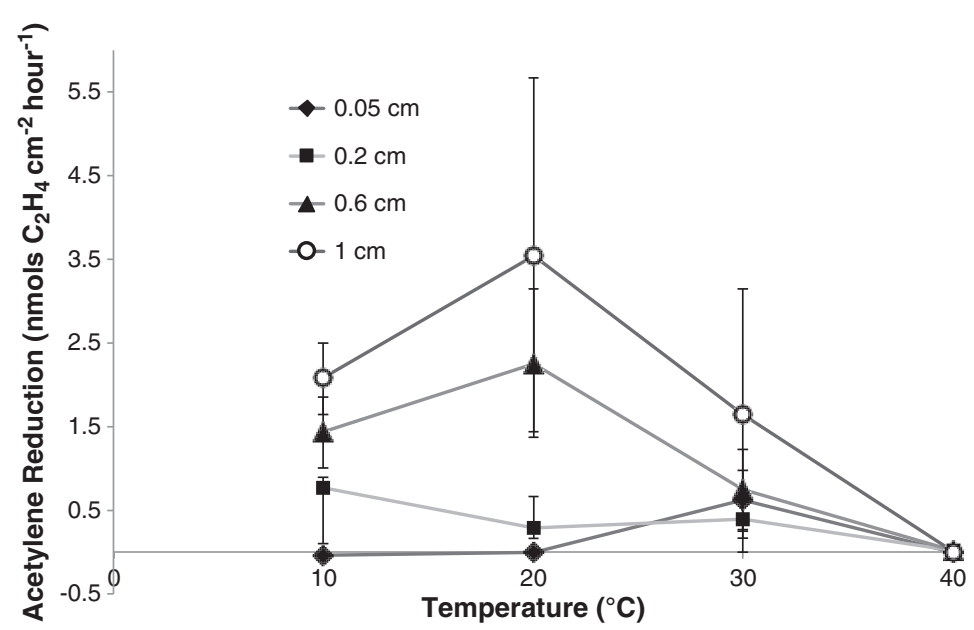

Figure 1 Acetylene reduction assays of biological nitrogen fixation activity in biologically crusted soils incubated under a range of temperature and moisture regimes. Values and means \pm 1 SE. (A) Light crust and (B) dark crust. Legend values indicate water additions to simulate $0.05,0.2,0.6$, and $1 \mathrm{~cm}$ rainfall events.

(Brankatschk et al. 2013; Table 2). The high denitrification rates observed on the central European dune systems may be due to high $\mathrm{N}$ deposition rates in the region, which ranged from 12 to $15 \mathrm{~kg} \mathrm{~N}_{\text {ha }}^{2}$ year ${ }^{-1}$ Elevated soil $\mathrm{NO}_{3}{ }^{-}$ due to high $\mathrm{N}$ deposition rates in these European dune systems may promote high rates of denitrification that would not be observed in biocrusts near Canyonlands National Park, UT, where $\mathrm{N}$ deposition rates are much lower ( $<2 \mathrm{~kg} \mathrm{~N} \mathrm{ha}^{2}$ year $^{-1}$; Sullivan et al. 2011).

Although denitrification rates were higher in dark biocrusts that exhibited higher $\mathrm{N}$ fixation rates relative to light biocrusts, denitrification rates were much lower than those observed beneath the $\mathrm{N}$-fixing shrub, P. glandulosa, in the Sonoran desert. Denitrification rates were two orders of magnitude lower in our study of $\mathrm{N}$-fixing biocrusts relative to the $\mathrm{N}$-fixing shrub P. glandulosa $\left(27,840 \mu \mathrm{g} \mathrm{N} \mathrm{m}{ }^{-2}\right.$ day $^{-1}$; Virginia et al. 1982). Following this, we would predict that denitrification rates will be enhanced by the presence of $\mathrm{N}$-fixing cyanobacteria and lichens in biocrusts, but rates are not on par with those observed in soils beneath symbiotic N-fixing plants.

There was no consistent effect of temperature on denitrification rates, but there was an interactive effect of water addition and biocrust type. In light crusts, denitrification rates increased with increasing water addition, whereas the highest denitrification rates (but also the most variable) in dark crusts were observed at the lowest level of water addition (Figure 2A, B, crust $\times$ water, $\mathrm{F}=3.93 P=0.001$ ). Previous studies of denitrification 

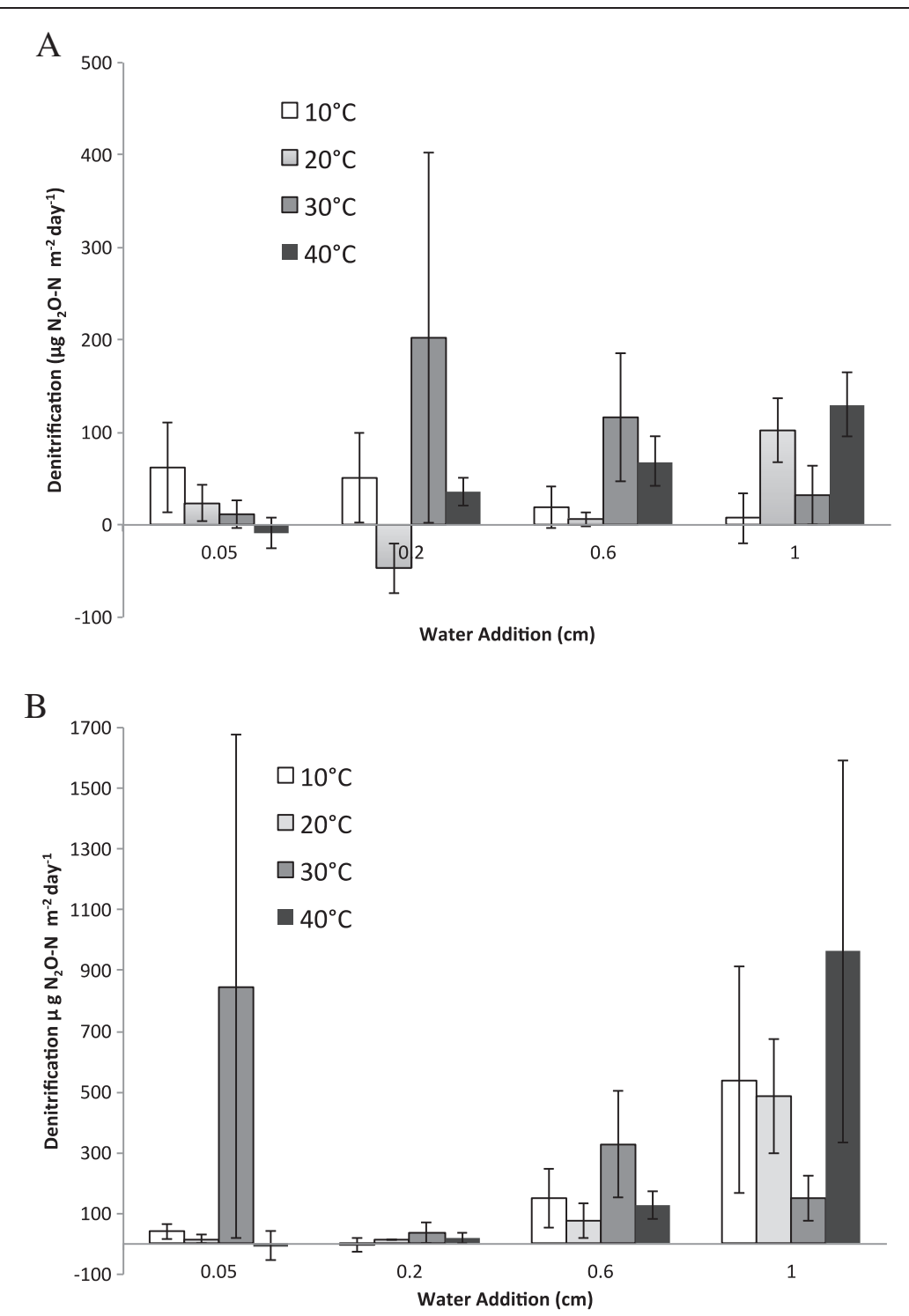

Figure 2 Denitrification rates in biologically crusted soils incubated under a range of temperature and moisture regimes. Values and means \pm 1 SE. (A) Light crust and (B) dark crust. Legend values indicate temperatures at which soils were incubated.

enzyme activity (DEA) in desert soils showed optimal activities at $40^{\circ} \mathrm{C}$ (Peterjohn 1991). In contrast to these results, some the highest denitrification rates in dark biocrusts in our study occurred at 10 and $20^{\circ} \mathrm{C}$ after a $1 \mathrm{~cm}$ simulated rain event (Figure 2B). Although the amount of water added did influence denitrification rates, it did not do so in a predictable manner. Percent soil moisture ranged from less than $1 \%$ in the $0.05 \mathrm{~cm}$ rainfall simulation up to $11 \%$ in the $1 \mathrm{~cm}$ rainfall in the top $0-2 \mathrm{~cm}$ of soil (mean \% soil moisture; $0.05 \mathrm{~cm}=$ $0.05 \% ; 0.2 \mathrm{~cm}=3 \% ; 0.6 \mathrm{~cm}=7 \% ; 1.0 \mathrm{~cm}=12 \%)$. These results are in contrast to previous studies that have shown strong differences in denitrification rates with varying soil moisture levels (Groffman and Tiedje
1988). Overall the lack of a consistent response to our temperature and water manipulations suggests that more traditional modeling approaches of denitrification dynamics, which are often based on environmental variables, would fail to adequately describe denitrification rates in biocrust soil systems.

The higher denitrification rates in dark biocrusts may be partially explained by the $22 \%$ higher soil organic C (Table 1) in addition to higher inorganic $\mathrm{N}$ pools relative to light biocrusts. Extractable soil $\mathrm{NO}_{3}{ }^{-}$in dark crusts was nearly two-fold higher than light crusts [Figure 3A, $\mathrm{B}$; mean $\mathrm{NO}_{3}^{-}\left(\mathrm{mg} \mathrm{NO}_{3}^{-} \mathrm{g} \mathrm{soil}^{-1}\right)$ : light $=0.68$, dark = 1.24]. Similar to the pattern in denitrification rates, there was an interactive effect of crust type and water addition 
Table 2 Estimates of $\mathbf{N}$ gas loss from biocrusts

\begin{tabular}{|c|c|c|}
\hline $\begin{array}{l}\text { Nitrogen fixation and } \\
\text { gas loss from biocrusts }\end{array}$ & $\begin{array}{l}\text { Light crust* } \\
\text { Early successional } \dagger \\
\mu \mathrm{N} \mathrm{N} \mathrm{m}^{-2} \text { day }^{-1}\end{array}$ & $\begin{array}{l}\text { Dark crust* } \\
\text { Later successional† } \\
\mu \mathrm{g} \mathrm{N} \mathrm{m}^{-2} \text { day }^{-1}\end{array}$ \\
\hline \multicolumn{3}{|l|}{ Denitrification } \\
\hline This study* & 48 & 418 \\
\hline \multicolumn{3}{|l|}{ (Colorado Plateau) } \\
\hline Johnson et al. 2007* & 5 & 7 \\
\hline \multicolumn{3}{|l|}{ (Colorado Plateau) } \\
\hline Strauss et al. $2012^{*}$ & 672 & Not reported \\
\hline \multicolumn{3}{|l|}{ (Colorado Plateau) } \\
\hline Brankatschk et al. 2013† & 3,360 & 6,720 \\
\hline \multicolumn{3}{|l|}{ (Germany inland dune) } \\
\hline \multicolumn{3}{|l|}{ Nitric oxide } \\
\hline Barger et al. 2005* & 229 & 335 \\
\hline \multicolumn{3}{|l|}{ (Colorado Plateau) } \\
\hline \multicolumn{3}{|l|}{ Ammonia volatilization } \\
\hline Evans and Johansen 1999 & Not reported & 15 \\
\hline Barger 2003* & 302 & 173 \\
\hline (Colorado Plateau) & & \\
\hline
\end{tabular}

Values were converted to mean $\mathrm{N}$ loss in $\mu \mathrm{N} \mathrm{m}^{-2}$ day $^{-1}$. $\mathrm{A} *$ indicates that the light and dark biocrust characterization was used to characterize biocrust type, whereas a + indicates an early and late successional biocrust.

on soil $\mathrm{NO}_{3}{ }^{-}$pools (crust $\times$water; $\mathrm{F}=2.70, P=0.05$ ) . Soils were extracted for standing inorganic $\mathrm{N}$ pools at the completion of the experiment, thus our reported values may not only reflect the $\mathrm{NO}_{3}{ }^{-}$pool remaining at the end of the experiment. In light crusts, patterns in $\mathrm{NO}_{3}{ }^{-}$pools were what we would expect, in that treatments that exhibited the highest denitrification rates had the lowest $\mathrm{NO}_{3}{ }^{-}$pools at the end of the experiment. Results from soil $\mathrm{NO}_{3}{ }^{-}$pools in the dark biocrusts were more mixed, but the $0.2 \mathrm{~cm}$ water addition that had exceedingly low denitrification did exhibit the highest extractable $\mathrm{NO}_{3}{ }^{-}$.

Extractable soil $\mathrm{NH}_{4}{ }^{+}$was nearly $40 \%$ higher in dark crusts relative to light crusts [Figure $3 \mathrm{C}, \mathrm{D}$; mean $\mathrm{NO}_{3}{ }^{-}$ $\left(\mathrm{mg} \mathrm{g} \mathrm{soil}^{-1}\right)$ : light $=0.66$, dark $\left.=1.00\right]$. There was also an interactive effect of temperature and water addition on soil $\mathrm{NH}_{4}{ }^{+}$, in which levels were two- to three-fold higher at the $40^{\circ} \mathrm{C}$ and highest levels of water additions (Figure 3C, D). High extractable $\mathrm{NH}_{4}{ }^{+}$levels at $40^{\circ} \mathrm{C}$ may be due to increased mineralization at this temperature but also declines in $\mathrm{NH}_{4}{ }^{+}$uptake by biocrusts. Although microorganisms within biocrusts fix $\mathrm{N}$, biocrusts may also exhibit high uptake rates of $\mathrm{NH}_{4}^{+}$ when active. Biocrust photosynthetic activity, however, declines dramatically at temperatures at or above $40^{\circ} \mathrm{C}$ (Lange et al. 1998). This pattern of $\mathrm{NH}_{4}{ }^{+}$release has been observed in previous studies, in which $\mathrm{NH}_{4}^{+}$production in soils peaked at approximately $50-60^{\circ} \mathrm{C}$ (Chantigny et al. 2010). Overall the higher soil organic $\mathrm{C}$ in addition to $\mathrm{NO}_{3}{ }^{-}$levels in dark biocrusts relative to light biocrusts may support the observed higher denitrification rates in our study.

\section{Coupling $\mathbf{N}$ fixation to denitrification}

The difficulty in estimating $\mathrm{N}$ loss via denitrification relative to $\mathrm{N}$ fixation in our experimental approach lies in uncertainties in estimating actual $\mathrm{N}$ fixed from AR assays. The theoretical conversion ratio of AR to actual $\mathrm{N}$ fixed is 3 , based on the biochemistry of the $\mathrm{N}$ fixation where six electrons are required for $\mathrm{N}_{2}$ reduction, whereas only two electrons are required for reduction of $\mathrm{C}_{2} \mathrm{H}_{2}$. Field and laboratory studies, however, have shown conversion ratios to vary dramatically, ranging from 0.022 to 22 (Rice and Paul 1971; Nohrstedt 1983, 1985; Montoya et al. 1996; Liengen 1999). In order to compare $\mathrm{N}$ losses in denitrification in this study to $\mathrm{N}$ fixation we used a conversion ratio of 0.295 , which was reported specifically for Nostoc commune cyanobacterial crusts in high arctic environments (Liengen 1999). These cyanobacterial communities are the most similar to the desert biocrusts evaluated in our study. Based on this, estimates of denitrification constitute 3 and $4 \%$ of $\mathrm{N}$ fixation rates of light and dark biocrusts, respectively (Figure 4). This proportion of $\mathrm{N}$ loss in denitrification is similar to Strauss et al. (2012) in that denitrification was ca. $3 \%$ of $\mathrm{N}$ fixation rates. In contrast denitrification rates from biocrusts at an inland dune in Germany were five- to ten-fold higher than $\mathrm{N}$ fixation rates (Brankatschk et al. 2013). It is important to note, however, that the Brankatschk et al. (2013) study was conducted in an area of high $\mathrm{N}$ deposition. In contrast, biocrusts from sites in our study and Strauss et al. (2012) were collected on the Colorado Plateau from areas of low $\mathrm{N}$ deposition. In areas of high atmospheric $\mathrm{N}$ deposition, we would predict that wet deposition of $\mathrm{NO}_{3}{ }^{-}$would elevate soil $\mathrm{NO}_{3}{ }^{-}$levels and may increase denitrification rates. Comparisons of denitrification in biocrusts relative to other gaseous $\mathrm{N}$ loss pathways in ecosystems with low $\mathrm{N}$ deposition rates suggest that denitrification rates are highly variable across studies but are generally within the range of nitric oxide and ammonia volatilization losses reported from previous studies (Table 2).

\section{Conclusions}

Our hypothesis that denitrification rates would increase with increasing $\mathrm{N}$ fixation potential of biologically crusted soils was supported in this study. Denitrification rates from dark cyanolichen biocrusts were eight-fold higher than light cyanobacterial crusts. In contrast to numerous studies across a broad range of ecosystems, 


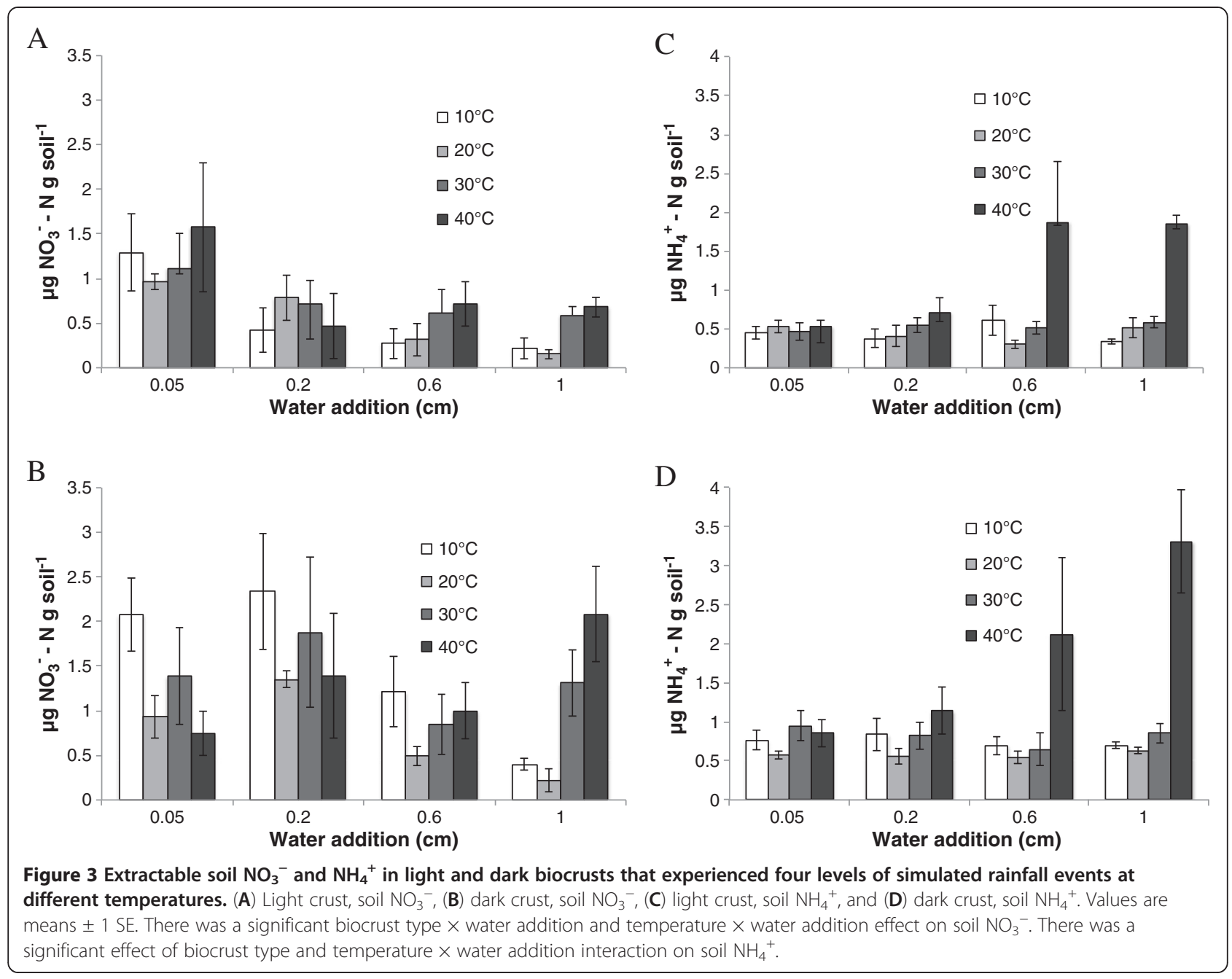

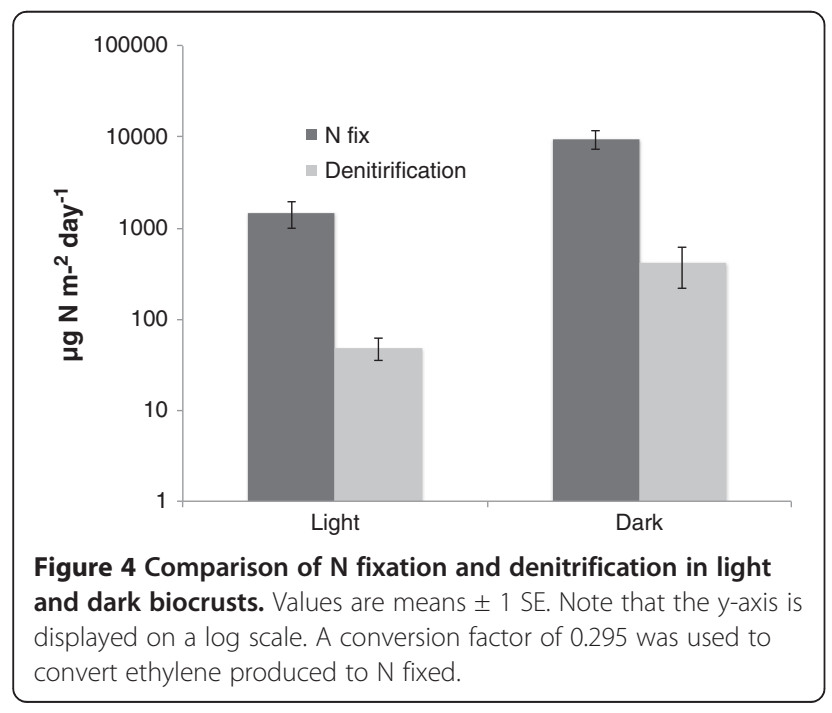

soil moisture and temperature had inconsistent and mixed effects on denitrification rates. Taken together, estimates of denitrification from light and dark biocrusts in this lab experiment constituted 3 and $4 \%$ of $\mathrm{N}$ fixation rates, respectively, indicating that denitrification rates are unlikely to be significant relevant to $\mathrm{N}$ inputs via fixation.

\section{Competing interests}

The authors declare that they have no competing interests.

\section{Authors' contributions}

N.B. provided financial support for the experiment, designed the experiment, collected the field samples, analyzed the data, and wrote the Introduction, Results and Discussion section. S.C. collaborated with NB in experimental design and field sample collection, conducted all the laboratory analyses, assisted in organizing and analyzing the data, wrote the initial draft of the Methods section, and edited the final drafts. G.D. researched a range of appropriate statistical analyses for the data, assisted in writing the Introduction, compiled all the references, and edited the manuscript. All authors read and approved the final manuscript. 


\section{Acknowledgements}

We would like to thank Heidi Guenther, Matt Ross, and Conor Morrison, who all helped conduct the laboratory experiment. In addition, we would like to thank Will Wieder and the Townsend Lab at the University of Colorado for assistance analyzing gas samples and Dr. William Adams for providing use of laboratory equipment. Finally, we would like to acknowledge the two anonymous reviewers and Dr. Bettina Weber for reviewing the manuscript.

\section{Author details}

${ }^{1}$ Department of Ecology and Evolutionary Biology, University of Colorado, Campus Box 334, Boulder, CO 80309-0334, USA. ${ }^{2}$ Department of Ecosystem and Conservation Sciences, College of Forestry and Conservation, University of Montana, Missoula, MT 59812, USA.

Received: 19 January 2013 Accepted: 23 May 2013

Published: 20 June 2013

\section{References}

Barger NN (2003) Biogeochemical cycling and N dynamics of biological soil crusts in a semi-arid ecosystem. PhD Dissertation, Colorado State University, Ft. Collins

Barger NN, Belnap J, Ojima DS, Mosier A (2005) NO gas loss from biologically crusted soils in Canyonlands National Park, Utah. Biogeochemistry 75:373-391

Belnap J (2002) Nitrogen fixation in biological soil crusts from southeast Utah, USA. Biol Fertil Soils 35:128-135

Belnap J, Harper K (1995) Influence of cryptobiotic soil crusts on elemental content of tissue of two desert seed plants. Arid Soil Res Rehabil 9:107-115

Belnap J, Rosentreter R, Leonard S, Kaltenecker JH, Williams J, Eldridge D (2001) Biological soil crusts: ecology and management. US Department of the Interior Technical Reference 1730-2, US Dept of the Interior, Denver

Belnap J, Phillips SL, Witwicki DL, Miller ME (2008) Visually assessing the level of development and soil surface stability of cyanobacterially dominated biological soil crusts. J Arid Environ 72:1257-1264

Billings SA, Schaeffer SM, Evans RD (2003) Nitrogen fixation by biological soil crusts and heterotrophic bacteria in an intact Mojave Desert ecosystem with elevated $\mathrm{CO}_{2}$ and added soil carbon. Soil Biol Biochem 35:643-649

Brankatschk R, Fischer T, Veste M, Zeyer J (2013) Succession of N cycling processes in biological soil crusts on a Central European inland dune. FEMS Microbiol Ecol 83:149-160

Castle SC, Morrison CD, Barger NN (2011) Extraction of chlorophyll a from biological soil crusts: a comparison of solvents for spectrophotometric determination. Soil Biol Biochem 43:853-856

Chantigny MH, Curtin D, Beare MH, Greenfield LG (2010) Influence of temperature on water-extractable organic matter and ammonium production in mineral soils. Soil Sci Soc Am J 74:517-524

Doane TA, Horwáth WR (2003) Spectrophotometric determination of nitrate with a single reagent. Anal Lett 36:2713-2722

Evans RD, Belnap J (1999) Long-term consequences of disturbance on nitrogen dynamics in an arid ecosystem. Ecology 80:150-160

Evans RD, Johansen JR (1999) Microbiotic crusts and ecosystem processes. Crit Rev Plant Sci 18:183-225

Garcia-Pichel F, Belnap J (1996) Microenvironments and microscale productivity of cyanobacterial desert crusts. J Phycol 32:774-782

Groffman PM, Tiedje JM (1988) Denitrification hysteresis during wetting and drying cycles in soil. Soil Sci Soc Am J 52:1626-1629

Guilbault MR, Matthias AD (1998) Emissions of $\mathrm{N}_{2} \mathrm{O}$ from Sonoran Desert and effluent-irrigated grass ecosytems. J Arid Environ 38:87-98

Gundlapally SR, Garcia-Pichel F (2006) The community and phylogenetic diversity of biological soil crusts in the Colorado Plateau studied by molecular fingerprinting and intensive cultivation. Microb Ecol 52:345-357

Hartley A, Schlesinger W (2002) Potential environmental controls on nitrogenase activity in biological crusts of the northern Chihuahuan Desert. J Arid Environ 52:293-304

Johnson SL, Neuer S, Garcia-Pichel F (2007) Export of nitrogenous compounds due to incomplete cycling within biological soil crusts of arid lands. Environ Microbiol 9:680-689

Kettler TA, Doran JW, Gilbert TL (2001) Simplified method for soil particle-size determination to accompany soil-quality analyses. Soil Sci Soc Am J 65:849-852

Lange OL, Belnap J, Reichenberger H (1998) Photosynthesis of the cyanobacterial soil-crust lichen Collema tenax from arid lands in southern Utah, USA: role of water content on light and temperature responses of $\mathrm{CO}_{2}$ exchange. Funct Ecol 12:195-202

Liengen T (1999) Conversion factor between acetylene reduction and nitrogen fixation in free-living cyanobacteria from high Arctic habitats. Can J Microbiol 45:223-229

Mayland HF, McIntosh TH (1966) Availability of biologically fixed atmospheric nitrogen-15 to higher plants. Nature 209:421-422

Montoya JP, Voss M, Kahler P, Capone DG (1996) A simple, high-precision, highsensitivity tracer assay for $\mathrm{N}_{2}$ fixation. Appl Environ Microbiol 62:986-993

Nohrstedt H (1983) Conversion factor between acetylene reduction and nitrogen fixation in soil: effect of water content and nitrogenase activity. Soil Biol Biochem 15:275-279

Nohrstedt $\mathrm{H}$ (1985) Nonsymbiotic nitrogen fixation in the topsoil of some forest stands in central Sweden. Can J For Res 15:715-722

Noy-Meir I (1985) Desert ecosystem structure and function. In: Evenari M (ed) Hot deserts and arid shrublands. Elsevier Science, Amsterdam

Peterjohn W (1991) Denitrification: enzyme content and activity in desert soils. Soil Biol Biochem 23:845-855

Peterjohn WT, Schlesinger WH (1990) Nitrogen loss from deserts in the southwestern United States. Biogeochemistry 10:67-79

Peterjohn WT, Schlesinger WH (1991) Factors controlling denitrification in a Chihuahuan desert ecosystem. Soil Sci Soc Am J 55:1694-1701

Rice WA, Paul EA (1971) The acetylene reduction assay for measuring nitrogen fixation in water-logged soil. Can J Microbiol 17:1049-1056

Schade JD, Marti E, Welter JR, Fisher SG, Grimm NB (2002) Sources of nitrogen to the riparian zone of a desert stream: implications for riparian vegetation and nitrogen retention. Ecosystems 5:68-79

Schlesinger WH, Pilmanis AM (1998) Plant-soil interactions in deserts. Biogeochemistry 42:169-187

Sherrod LA, Dunn G, Peterson GA, Kolberg RL (2002) Inorganic carbon analysis by modified pressure-calcimeter method. Soil Sci Soc Am J 66:299-305

Strauss SL, Day TA, Garcia-Pichel F (2012) Nitrogen cycling in desert biological soil crusts across biogeographic regions in the southwestern United States. Biogeochemistry 108:171-182

Sullivan TJ, McDonnell TC, McPherson GT, Mackey SD, Moore D (2011) Evaluation of the sensitivity of inventory and monitoring of National Parks to nutrient enrichment effects from atmospheric nitrogen deposition. Nat Resour Rep NPS/NRPC/ARD/NRR 2011/321, US Dept of the Interior, Denver

Virginia RA, Jarrell WM, Franco-Vizcaino E (1982) Direct measurement of denitrification in a Prosopis (Mesquite) dominated Sonoran Desert ecosystem. Oecologia 53:120-122

Weatherburn MW (1967) Phenol-hypochlorite reaction for determination of ammonia. Analytical Chem 39:971-974

West NE, Skujins JJ (1977) The nitrogen cycle in North American cold-winter semi-desert ecosystems. Oecol Plant 12:45-53

Williams EJ, Hutchinson GL, Fehsenfeld FC (1992) $\mathrm{NO}_{x}$ and $\mathrm{N}_{2} \mathrm{O}$ emissions from soil. Glob Biogeochem Cycles 6:351-388

Yeager CM, Kornosky JL, Housman DC, Grote EE, Belnap J, Kuske CR (2004) Diazotrophic community structure and function in two successional stages of biological soil crusts from the Colorado Plateau and Chihuahuan Desert. Appl Environ Microbiol 70:973-983

Zaady E (2005) Seasonal change and nitrogen cycling in a patchy Negev Desert: a review. Arid Land Res Manage 19:111-124

Zaady E, Groffman PM, Shachak M (1998) Nitrogen fixation in macro- and microphytic patches in the Negev desert. Soil Biol Biochem 30:449-454

\section{doi:10.1186/2192-1709-2-16}

Cite this article as: Barger et al:: Denitrification from nitrogen-fixing biologically crusted soils in a cool desert environment, southeast Utah USA. Ecological Processes 2013 2:16. 